\title{
Cultural Translation and Mamoni Raisom Goswami's Thang Fhâkhri Tahcildârar Tâmar Tarowâl
}

Purabi Goswami

https://orcid.org/0000-0001-7147-6311

Handique Girls' College, Guwahati

\begin{abstract}
The act of translation cannot be called a simple act of conveyance because a text is a product of a cultural milieu. Hence when a text is translated it does not remain a plain act of transfer from one language to another, it becomes an act of cultural transference. The paper dwells on this aspect of translation and analyses my own experience of translating Mamoni Raisom Goswami's Thang Fhâkhri Tahcildârar Tâmar Tarowâl.
\end{abstract}

Keywords: Culture, Translation, Original Text, Translated Text, Untranslatability.

The idea of culture is not specific and definitive. We can go back to Lock's theory of tabula rasa to define it where the human mind is a template where experience writes. It is an interactive process that is influenced by our familial orientations, our processes of socialization, which also include our beliefs, attitudes, and the values prevalent in our religion. Roughly the term denotes human activities in a social context and on an individual level. Many critics and scholars have defined culture in their own ways. Matthew Arnold bestowed the idea of culture on art and literature and said in the preface to Culture and Anarchy that humanity can be acquired by learning "the best which has been thought and said in the world." Similarly, F. R. Leavis and T. S. Eliot provided a liberal or radical conservative idea of culture, reserving culture only for a small number of people, i. e. the elite class. Raymond Williams, on the other hand, points to the

This open-access work is licensed under a Creative Commons Attribution Noncommercial 4.0 International License. For more information visit https://creativecommons.org/licenses/by-nc/4.0/ 
transformation the idea of culture has undergone: "Civilization and culture ... were in effect, in the late eighteenth century, interchangeable terms. Each carried the problematic double sense of an achieved state and of an achieved state of development" (Goodenough 15). However, Goodenough's definition can be used as a working definition for our purpose as we are more interested in the anthropological view where culture is a whole way of life. Goodenough says: “As I see it, a society's culture consists of whatever it is one has to know or believe in order to operate in a manner acceptable to its members and do so in any role that they accept for anyone of themselves [...]. By definition, we should note that culture is not a material phenomenon; it does not consist of things, people, behavior, or emotions. It is rather an organization of these things. It is the form of things that people have in mind, their model of perceiving and dealing with their circumstances" (Goodenough 36). The way, in which people speak, construct their sentences, choose their vocabulary (according to the formal/informal situation they are in, to their geographical origin and so on) reveals much about their culture.

Now if we come to another key term in our paper i. e. translation; the act of translation involves two languages. Traditionally translation was seen as a subfield of linguistics. J. C. Catford's book A Linguistic Theory of Translation: An Essay in Applied Linguistics (1965) revealed this type of an assumption where he defines translation as "a process of substituting a text in one language for a text in another" (Catford 1). This method of studying translation was replaced by an emphasis on extra-linguistic factors. The question of equivalence and faithfulness in translation was replaced by broader issues of context, history and convention. As Bassnett and Lefevere say: "The object of study has been redefined; what is studied is text embedded within its network of source and target cultural signs" (Bassnett and Lefevere, 12). However, a historical situation, cultural memory and an individual's perception of all these are revealed in 
language. Language is something with which the experience of a community is associated. As Pramod Talgeri says:

"Word is not just a lexical entity. To a creative writer, word is essentially a cultural memory, in which the entire society participates. The experience of the society has gone into this word. The society remembers and recapitulates this experience, when this word is put into a context, which rejuvenates history and creates coherence in the appropriation of our experience. Individual reader shares this experience of social participation by way of reading literature" (Talgeri 29).

The act of translation involves the challenging task of recreating and recontextualising this participatory experience of the source culture in the target language. At this point, if we refer to a critic like Derrida the question of an origin and a translated text do not exist. Derrida writes:

"Within the limits of its possibility, or its apparent possibility, translation practices the difference between signified and signifier. But, if this difference is never pure, translation is less so, and a notion of transformation must be substituted for the notion of translation; a regulated transformation of one language by another, of one text by another" (Devy 145).

Derrida brings in the idea of signifier and signified and says that the original text is not the signified as we think traditionally, he talks about the idea of the signifier in terms of language. It does not matter whether it is the original or the translated text a meaning can never be captured, it slips. A translation displaces the possibility of grasping that which the original text desired to name. Along with it, a text is a cultural product. It involves the taste of a particular language community and on this taste depends the marketing strategies of publishers. If a book is a product of a socio-cultural milieu, then it also has a socio-cultural purpose. In this perspective 
the act of translation becomes relevant. The translation is the medium of cultural interaction between two language groups. In India, the translation of different texts in Indian languages started in the colonial age. We cannot deny the vested interests of the colonisers in those translations. As Lefevere says: “... can culture A ever really understand culture Bon that culture's (i.e. B's) own terms? Or do the grids always define how cultures will be able to understand each other? Are the grids, to put it in terms that may well be too strong, the prerequisite for all understanding or not?" (Lefevere 77). These grids pertain when a text is translated from an Indian language into English, the language of the colonising power. Now British are no longer our colonial masters. Yet something like what K. Raghavendra Rao calls 'internal colonialism' (Rao 88) persists. He further says, "Our present roots already lie tangled with foreign roots" (Rao 91). At this juncture, it is impossible for us to write either in English or in any Indian language being rooted in purely Indian culture. Apart from this, the problem persists in a different way. For instance, when a text in any Indian language is translated into a foreign language, the cultural 'distance' between the languages involved affects the act of translation. In an essay entitled “Missi Versus Lipstick: Problems of Translating Indian Literature into English" (Narang 99) Harish Narang refers to the translation of Premchand's Shatranj Ke Khilari. One translator translates the words 'hakim' and 'divankhana' as 'doctor' and 'drawing room'. Another one translates the word 'cilam' as 'pipe' which is not a near equivalent. He refers to the word 'missi' which means a particular colour made from the barks of a tree to colour the lips. To translate it as lipstick leads to the loss of socio-cultural meaning. For instance, the concept of Suhag (the image of a married woman with bangles, colourful sarees and vermillion) is completely missing from the English culture. For a sketchy discussion of these types of pros and cons of cultural translation this paper analyses the translation of a novella written by Mamoni Raisom Goswami 
entitled Thang Fhâkhri Tahcildârar Tâmar Tarowâl. Thang Fhâkhri Tahcildârar Tâmar Tarowâl is a result of the writer's curiosity in the title character. The author heard about Thang Fhâkhri from the folktales and folksongs in her childhood which eventually resulted in her interest to write a novel about this legendary woman from a little-known tribe and which does not find a place in history either. The novel, Thang Fhâkhri Tahcildârar Tâmar Tarowâl is centrally about a Bodo woman. The story is rooted in a pre-independence socio-cultural and political situation around Bijni in the west of Assam bordering Bengal. The novel abounds in its reference to the living conditions of the Bodo community. According to Dr. Birinchi Kr. Barua, Boro-Kachari follows a matriarchal system. At the time of marriage people from the Boro girl's village take money from the groom's side (Narzi, 21-22). In the novel, Thang Fhâkhri's grandfather Tribhuban Bahadur says there was no 'sati' among the Bodos and Thang Fhâkhri was a widow (Goswami 37). Moreover, the sword she uses belongs to a ruined temple of Devi Durgâ. The story talks about the importance of agriculture in the lives of Bodo folk. Overall, the novella can be called a pictorial representation of the Bodo way of life in words. It does the work of excavating history and inserting it into fictional accounts. Now if we talk about the practical experience of translating the text there remains some remarkable difference between the original and the translated text. The novel abounds in its reference to some historical characters around Bijni and certain geographical locations in that area. For instance, in their reply to the curious non-Assamese visitors, one of Thang Fhakhri's villagers says about the practice of 'sati': "This practice is there among the royalty. Five queens were burnt with king Mukundadev" (Goswami 39). Now the translator will have to provide a small narration on king Mukundadev and his wife's immolation. It can be done through the help of a glossary. Yet as Sapir says language "not only refers to experience largely acquired without its help, but actually defines experience (Sapir 
57)." In this case the reader will be deprived of both the experience. There is a long description of king Bijaynarayan too. Tribhuvan Bahadur tells: "Our king Bijoynarayan was a beloved among his subjects. The king understood the tricks of the company before anyone could fathom about it. We heard he talked with the musa general at the dock of Goalpara. One painter of the company drew picture of the king and the general" (Goswami 40). Apart from this, there are references to Bodo mythological stories. Tribhuvan Bahadur describes how jumai is so sacred for the Bodos:

In Bodo wine is called Jumai Jou. Others call it Laupani. We offer our wine to Lord Shiva. Then the four soldiers shouted together- 'Hail to Lord Shiva.' Bahadur continued — The discovery and making of this wine are very mysterious. It is as if nature has made it for us. We are blessed by Lord Shiva. Listen, once a woodcutter became very tired and fell asleep under the very tree which he was to cut. The old man woke up by the chirping sound of some birds. The old man saw his whole body was covered with leaves and petals of flowers. The man looked up and saw the birds assembled in the tree in a manner as if they were all fairies. So many birds! Bhimraj, Tiya, Bulbuli...Occasionally the birds went inside a hollow in the tree and took some liquid and start dancing after that. The old man too took some from the hollow. - Immediately he got a new energy. He took some for his wife in a bamboo tube. After taking the drink the old woman started dancing. Both the man and the woman danced together. - The old couple finished the wine in two days. They were very sad for that. Looking at the sorry state of the couple Lord Shiva came down from heaven and taught them how to make that wine. The old man and the woman became expert in preparing this wine and now in our society this wine is dear to all. We keep this wine separate for our guests (Goswami 40). 
The Bodos are called Anârjya. This binary is made after the Bodos came into contact with the Arjyâ around 1000 BC (Bhaben 2). Shiva is the prime god for them, unlike the Hindus who have different gods and goddesses. The story talks about the importance of agriculture in the lives of Bodo folk. People from other states came to meet the Bodos to learn their ways of cultivation. The novel shows that the lives of the Bodos were ingrained in agriculture. Mr Endle too describes the ingenuity of the Bodos in cultivation. He writes: "Moreover, the people are especially skilful in the construction of irrigation canals and earthwork embankments for diverting water from riverbeds into their ricefields: and their efforts in this direction are very largely aided by their closely clannish organization" (Bhaben 13). A dialogue by a Portuguese man in the novel reveals how despite all their hard labour the Bodos were still the underprivileged: "Bodo brothers, you can even drag the river Manah and the river Kalahi and compel them to fall into the paddy field! Yet you are in this pitiable condition. Why is it so, why? (Goswami 33) Overall the novella can be called a pictorial representation of the Bodo way of life in words. Along with this, there are detailed geographical descriptions of the places around Bijni. For instance, the writer describes how the young people from different places join the freedom: "It is rumoured some young people residing in Darrang, Kamrup and near the Champavati River have entered into the forest in groups... They have formed a kind of gunpowder station in the forest. These things are known to Banikhata, Nadangbari, Kalabari of Bijni and the residents near the bank of Manas" (Goswami 62). These things are incomprehensible not only for the non- Assamese readers but for those readers too who do not have much idea about geographical locations of pre-independent lower Assam. Moreover, certain expressions are rooted in the structure of Assamese society and the Assamese language. An expression like chegâcherekâkoi garam batâh baliche I translate as 'rebel winds occasionally 
blew.' I think the word 'occasionally' cannot do justice to the literariness of the word 'chegâcherekâkoi' (Goswami 88). The writer compares the lines on Thang Fhakhri's forehead with a 'trident' (Trishul). In English, there is no equivalent word for that. In the first chapter itself, the writer compares the Brahmaputra in the evening time with a priest red with sacrificial blood. This is a pan-Indian phenomenon but for a reader outside India, even a glossary may not be sufficient to illuminate them about the cultural connotations of these statements. The image of the Trishul with the colour red is recurrent in Goswami's writings. This points to the impact of the sacrificial rites and the image of Devi Durgâ in the writer's psyche since her childhood. In these instances, the interactive function of bridging the gap fails due to linguistic constraints. There are expressions like 'kalpât falâdi fâlisil (Goswami 19), 'sâtghâtar pâni khuwa tâtu'(Goswami 22), 'bândar kekowâi powâ' 'ekuri’ (Goswami 29), 'hoibhor'(Goswami 35) which are not possible to translate. As Walter Benjamin says, "Unlike the words of the original, it is not translatable, because the relationship between content and language is quite different in the original and the translation." (Lawrence Venuti, 79) The names of certain trees like 'gondhosoroi', 'úilikhâ', 'fulsampâ', 'fâmiful' cannot be translated. There are no equivalent words for these names. Moreover, certain expressions are rooted in the religio-cultural milieu of Assamese society. A word like 'ista devatâ' is an example of that. 'Ista devatâ' means the god whom one worships. This type of expression is rooted in the conventional linguistic system of the community. There are references to Mughal rule, economic relations between Bhutan and India. These are small historical information that is difficult to convey to an alien culture. The relationship between India and Bhutan, the constitution of the Bijni duar, the position of the Bodos at that time- even indigenous Assamese people are not aware of these historical facts because of scanty historical material available. The depiction of Thang Fhâkhri is very striking. 
A typical Bodo woman donning dokhna (Bodo woman's attire), but at the same time riding a horse with the British sahibs to collect revenue wearing riding breeches and hat over long hair. In this context, the writer provides an elaboration on different varieties of dokhnas the Bodo woman uses. So, to transfer this social, cultural and political information in translation is a challenging task. These, then are some of the problems that a translator encounters in translating a regional Indian text into a foreign language. Yet without the translation of Indian literature into English, we can never make Indian literature a part of world literature. In translation recontextualisation of the source text into the target text in terms of language and culture is not possible. Walter Benjamin's idea of 'untranslatability' prevails. Benjamin says: "Unlike the words of the original, it is not translatable, because the relationship between content and language is quite different in the original and the translation" (Venuti 79). Considering these issues the act of translation can be considered as a transaction as Chandrashekhar Patil does. He writes: "Translation, after all, is a transaction. One should be prepared to lose on one count only when some gain on some other count is guaranteed. The give and take between the words can be justified only after the bargain is over" (Patil176-177).

\section{Works Cited}

Bassnett, Susan and Andre Lefevere. Translation, History and Culture. Pinter, 1990.

Desai, K. Shantinath. Creative Aspects of Indian English. Sahitya Academy, 1995.

Devy, G. N. In Another Tongue Essays on Indian English Literature. Macmillan,1995.

Endle, Rev. Sidney. The Kacháris. Akansha Publishing House, 2010.

Goodenough, Ward H. "Cultural Anthropology in Linguistics” Language in Culture and Society. A Reader in Linguistics and Anthropology edited by D. Hymes, Harper \& Row, 1964. 
Goswami, Mamoni Raisom. Thang Fhâkhri Tahcildârar Tâmar Tarowâl. Jyoti Prakashan, 2009.

Lefevere, Andre. "Composing the Other". Postcolonial Translation: Theory and Practice. Routledge, edited by S. Bassnett and H. Trivedi, 1999.

Narzi, Bhaben. Bodo Kachârîr Samâj âru Sanskriti. Bina Library, 1985.

Sapir, Edward. Selected Writings in Language, Culture and Personality, edited by David Mandelbaum. University of California Press, 1949.

Stefan Collini, editor. Culture and Anarchy and Other Writings. Cambridge University Press, 1993.

Talgeri, Pramod and S. B. Verma, editors. Literature in Translation From Cultural Transference to Metonymic Displacement. Popular Prakashan. 1988.

Venuti, Lawrence, editor. The Translation Studies Reader. Routledge, 2004.

Williams. Raymond. Marxism and Literature. OUP, 1977.

\section{Bionote:}

Turabi Goswami is an Assistant Professor in the Department of English at Handique Girls' College, Guwahati, Assam, India. Email: purabee.lng@ gmail.com

ORCID ID: https://orcid.org/0000-0001-7147-6311

\section{Open Access:}

This article is distributed under the terms of the Attribution-NonCommercial 4.0 International (CC BY-NC 4.0) (https://creativecommons.org/licenses/by/4.0/) which permits any use, reproduction and distribution of the work without further permission provided the original work is attributed as specified on the Transcript: An e-Journal of Literary and Cultural Studies. For more information log on to http://thetranscript.in/

\section{Conflict of Interest Declaration:}

The author declared no potential conflicts of interest about the research, authorship and publication of this article.

(C) Author 